University of Maryland Francis King Carey School of Law

DigitalCommons@UM Carey Law

Faculty Scholarship

Francis King Carey School of Law Faculty

2014

\title{
Unexpected Links Between Baby Markets and Intergenerational Justice
}

Martha M. Ertman

University of Maryland School of Law, mertman@law.umaryland.edu

Follow this and additional works at: https://digitalcommons.law.umaryland.edu/fac_pubs

Part of the Family Law Commons, and the Human Rights Law Commons

\section{Digital Commons Citation}

8 Law and Ethics of Human Rights 271 (2014).

This Article is brought to you for free and open access by the Francis King Carey School of Law Faculty at DigitalCommons@UM Carey Law. It has been accepted for inclusion in Faculty Scholarship by an authorized administrator of DigitalCommons@UM Carey Law. For more information, please contact smccarty@law.umaryland.edu. 
Martha M. Ertman*

\title{
Unexpected Links between Baby Markets and Intergenerational Justice
}

\begin{abstract}
Intergenerational justice does not require increased government regulation of reproductive technologies in the United States. Arguments tarring reproductive technologies as unnatural or immoral fail to withstand close scrutiny, and moreover ignore competing moral concerns like the liberty and equality of people to form families in different ways, as well as the interests of children born via assisted reproduction in having their families recognized just as coitally conceived children's families are recognized. Embryo markets, in contrast, might present different challenges, requiring a separate analysis of their potential impact on intergenerational justice.
\end{abstract}

\section{Introduction}

Most people object to markets in babies, often invoking intergenerational justice to support their condemnation. Margaret Jane Radin, for example, says to speak of children in market terms harms personhood. ${ }^{1}$ Michael Sandel condemns gamete markets as either coercive to adults, corrupting to the giftedness of having children, or both. ${ }^{2}$ But a close look at gamete markets - and their coital alternative - shows that these markets are not inherently unjust to coming generations, at least no more so than coital means of reproduction.

On the coital front, adults routinely select the characteristics of children they conceive through mate selection, just as buyers in gamete markets select donors with particular traits like height, intelligence, and good health. Moreover, if the

1 Margaret Jane Radin, Contested Commodities 139 (1996).

2 Michael J. Sandel, What Money Can't Buy: The Moral Limits of Markets, in Rethinking Commodification: Cases and Readings in Law and Culture 122 (Martha M. Ertman \& Joan C. Williams eds., 2005); Michael J. Sandel, The Case Against Perfection: Ethics in the Age of Genetic ENGINEERING (2007).

*Corresponding author: Martha M. Ertman, Carey Law School, University of Maryland, College Park, MD 20742, USA, E-mail: mertman@law.umaryland.edu 
concern is that children conceived with donor gametes don't know both of their genetic parents, many more children - virtually all conceived through coitus are placed with adoptive parents each year, which often, though not always, separates them from genetic kin. Finally, people who find the taint of lucre troubling enough to justify state interference in gamete markets should pause to also consider the vast sums already circulating in the dating and marriage markets, not least the billions that couples and their friends and family spend each year on weddings. In short, more similarities exist between assisted and coital reproduction than people think, and therefore less reason for the state to depart from its general tendency to leave private family decisions to the private realm by interfering in baby-making with purchased gametes.

Another aspect of government interference in reproductive technologies is the problem known to philosophers as the non-identity problem, which gets considerable attention in this symposium and elsewhere. Glenn Cohen has asked whether state limits on assisted reproduction - excluding would-be parents on the basis of their age, marital status and sexual orientation - can be justified on the best interests of the child, since those limits would prevent the child being born, an interest that surely outweighs any hardship endured by the child by virtue of having middle-aged, single, or gay parents. ${ }^{3}$ David Heyd's essay in this symposium takes a different approach, flagging the risk of Cohen's approach to other issues like abortion rights if law were to give weight to the interests of the yet-unborn. ${ }^{4}$ This essay does not engage the non-identity problem, other than to urge people wringing their hands over assisted reproduction to remember that these market mechanisms allow children to come into being who would not otherwise be born, and that society as a whole, in addition to individual parents and children, generally are benefitted by the presence of children in the world. ${ }^{5}$

This essay resists state limits on gamete markets for a different reason. Because limits on reproductive technologies involve state meddling in familybuilding decisions that are all but unthinkable in coital reproduction, justice requires us to ask why law would impose coercive controls in one case and give freedom and privacy in the other. One might claim that families ought not be formed with reproductive technologies because those families are unnatural contrary to biological or divine mandate - because coital reproduction is the

3 I. Glenn Cohen, Regulating Reproduction: The Problem with Best Interests, 96 Minn. L. Rev. 423, 450-7 (2011).

4 David Heyd, Parfit on the Non-Identity Problem, Again, 8 (1) L. \& Eтнісs Huм. Rтs. (2014).

5 For a bracing account of the social and economic ramifications of decreases in young people, see Ted C. Fishman, Shock of Gray (2010). 
only natural way to conceive a child. In intergenerational justice terms, this view seems to argue that children are so disserved by coming into the world via purportedly unnatural means, and growing up in an unnatural family that law ought to prevent those families from coming into being. My forthcoming book Love \& Contracts rejects this view.

Instead, in my book, and this essay, I argue that families formed through reproductive technologies are not less natural, just less common than coitally produced parenthood. (Other chapters concern adoption, cohabitation, and marital agreements, areas about which one could make different arguments regarding intergenerational justice.) Love \& Contracts documents ways that both law and culture continue to move away from outdated notions that only one "natural" form of family exists and toward a view of family that recognizes the different ways that people form families. ${ }^{6}$ Because both children and parents benefit from legal and social recognition of the various forms their families take, just laws would ensure access to reproductive technologies by prohibiting discrimination on the basis of, for example, marital status and sexual orientation, and unjust laws would limit access on those grounds. Since legislators in the United States and elsewhere may well display much more enthusiasm for limiting access, I take the view that law ought to refrain from meddling in intimate decisions about family building in medical offices, just as it does when those decisions occur in bedrooms. In other words, sometimes the laws of supply and demand can do a better job than state or federal law. ${ }^{7}$

Legal interventions in families are infamously unjust, especially when lawmakers draw distinctions between worthy and purportedly less-worthy families. Consider the 1996 Welfare Reform, Defense of Marriage Acts, and widespread opposition to decisions such as Goodridge v. Dep't of Health that recognize samesex couples' rights to marry. ${ }^{8}$ Supporters of measures to limit access to reproductive technologies would do well to pause and consider commonalities between their proposals and other moralist interventions meant to police minority family forms. Both elevate family form over substance, protecting some

6 Martha M. ERtman, Love \& Contracts (forthcoming, Beacon Press 2015).

7 The laws of supply and demand in reproductive technologies do not serve all populations well. Racial minorities, whether single, gay, or heterosexual and coupled, who have higher rates of infertility than whites, paradoxically have had less access to reproductive technologies. DoRothy Roberts, Killing the Black Body 252 (1997).

8 The Personal Responsibility and Work Opportunity Reconciliation Act of 1996, Pub. L. No. 104-93, 110 Stat. 2105 (codified at 42 U.S.C. §1305); The Defense of Marriage Act, 1 U.S.C. §7 (2006); Goodridge v. Dep’t of Health, 798 N.E.2d 941 (Mass. 2003); Varnum v. Brien, 763 N.W.2d 862 (Iowa 2009); A.G. Sulzberger, In Iowa, Voters Oust Judges over Marriage Issue, N.Y. Times, Nov. 3, 2010, available at http://www.nytimes.com/2010/11/03/us/politics/03judges.html?_r=0. 
children's families - with married, heterosexual parents - by labeling them natural and morally superior, and relegating everyone else to the category unnatural and immoral.

This essay first reviews and critiques the arguments that markets in gametes are unnatural or immoral, then offers Viviana Zelizer's socioeconomic theoretical framework as a better way of viewing the complex ways that exchange and families interact. It concludes by suggesting that gamete markets do not threaten intergenerational justice, at least no more than other methods of becoming a parent.

\section{Common Objections to Markets in Gametes}

\section{Misperceiving Reproductive Technology as Unnatural}

Religious and secular commentators alike have condemned markets in gametes as unnatural. ${ }^{9}$ But "natural" is a big category, encompassing both claims to divine or biological mandates, so that arguments from nature can justify mutually exclusive alternatives. While the Catholic Church claims that forms of intimacy other than monogamous marriage are unnatural because of divine mandate, it is equally possible to say that polygamy is "natural" in that it's biologically mandated by evolutionary forces, which explains its prevalence among human and animal populations. ${ }^{10}$ Different religious communities likewise claim moral authority for mutually exclusive positions. Some claim that

9 See, e.g. Miriam Zoll, Cracked Open: Liberty, Fertility and the Pursuit of High-Tech Babies (2013) and Donum Vitae, Congregation for the Doctrine of the Faith, Feb. 22, 1987, available at http://www.vatican.va/roman_curia/congregations/cfaith/documents/rc_con_cfaith_doc_19870222_ respect-for-human-life_en.html, a policy instruction issued by the Catholic Church condemning assisted reproduction generally. The Church currently enforces this policy by, for example, firing teachers in Catholic schools who get pregnant via alternative insemination and IVF, even if they were married and used their husband's sperm. Brian Roewe, Jury Rules for Cincinnati Catholic School Teacher Fired after Artificial Insemination, NaT'L Catholic REPORTER, June 4, 2013, http://ncronline.org/blogs/ncr-today/jury-rules-cincinnati-catholicschool-teacher-fired-after-artificial-insemination; Charles Wilson \& Emily Herx, Teacher Claims She Was Fired from Catholic School for In Vitro Fertilization, Hufrington Post, Apr. 25, 2012, available at http://www.huffingtonpost.com/2012/04/25/catholic-school-ivf_n_Charles. $\mathrm{html}$ ?view=print\&comm_ref=false.

10 David P. Barash \& Judith E Lipton, The Myth of Monogamy (2001); Martha M. Ertman, The Story of Reynolds v. United States: Federal "Hell Hounds" Punishing Mormon Treason, in Family Law StoRies 51 (Carol Sanger ed., 2008); Martha M. Ertman, The Story of Reynolds v. United States: Federal "Hell Hounds" Punishing Mormon Treason, in Family Law StoRIEs 51 (Carol Sanger ed., 2008). 
heterosexuality is morally superior to same-sex sexuality, while others claim that discrimination against gay people is morally wrong. ${ }^{11}$ An additional problem with the term "natural" it its aura of inevitability - evident in the phrase "it's only natural" - which too often translates to overlooking exceptions to the general rule, as when people create families with assistance after luck or biology block the common way to conceive a child. ${ }^{12}$

The crux of moral or nature-based opposition to reproductive technology seems to be resistance to seeing family building in contractual terms. It should just happen, driven by biology or divine inspiration, with little human thought or intervention. Rationally selecting the characteristics of a sperm donor from an online catalog seems unnatural and immoral, in this view, because it asserts human agency over a process properly left to God or biology. Leaving the theological arguments to others, this essay critiques the biology part of that claim, arguing that it is entirely natural to speak of family-building and contracts in the same breath.

\section{Family Contracts in the State of Nature}

A good number of evolutionary scientists argue that it is "natural," in the sense of a biological drive or evolutionary imperative, to form lasting relationships, to connect. Back-and-forth exchanges provide a key method of connecting. (I use the terms "contract" and "exchange" more or less interchangeably, recognizing that much of the timeframe explored by evolutionary biology predated courts, and even language, and therefore, of course, the understanding of a contract as a legally binding agreement.)

These scholars tell a story that starts long ago and far away, when our apelike ancestors began what anthropologist Helen Fisher calls "the most fundamental exchange the human race would ever make."13 Our hairy fore-mothers, she explains, spent much of their days collecting roots and other vegetables,

11 Michael J. Broyde \& Michael S. Berger, Marriage, Sex and Family in Judaism 225-27, 252-53, 256-57 (2005); Jay Michaelson, God vs. Gay?: The Religious Case for Equality (2011).

12 Another defect in this reasoning lies in the fact that what constitutes the "natural" family changes over time. Anthropologists view family through the lens of kinship, and note how kinship exists on the border of nature and culture by providing the cultural context for biological functions of procreation. Marilyn Strathern, Reproducing the Future: EsSays on Anthropology, Kinship and the New Reproductive Technologies 17 (1992). Strathern notes that over the course of the twentieth century "nature" increasingly became biologized, which has in turn biologized the idea of natural kinship. Id. at 19.

13 Helen E. Fisher, The Sex Contract: The Evolution of Human Behavior 94, 99-100 (1982). 
while their male counterparts ranged over wider territory hunting for a rabbit or mongoose. But while their ancestors had mated freely, these proto-humans gradually formed a pair bond exchange. A female would focus her sexual and grooming attention on a male and share her foraged vegetables with him, while he, in turn, would share his proceeds from the hunt. Sociobiologists believe that whether these relationships lasted a few months, a year, or a lifetime, they were reciprocal. The female expected a share of meat brought back from hunting, and the male expected a share of "her" vegetables. Gradually, Fisher contends, males also began to protect females from dangers like other animals, and, over thousands of years, males also began to help feed and protect the young. That exchange slowly transformed those children from "hers" into "theirs."

E.O. Wilson, known as the father of sociobiology, contends that these malefemale pair bonds helped greatly in caring for completely helpless human babies and raising children through the ten-plus years it takes humans to become self-sufficient. Pooling resources was absolutely essential to get children to reproductive age so they could start the cycle again. ${ }^{14}$ Wilson explains:

Mothers carry fetuses for nine months and afterward are encumbered by infants and small children who require milk at frequent intervals through the day. It is to the advantage of each woman of the hunter-gatherer band to secure the allegiance of men who will contribute meat and hides while sharing the labor of child-rearing. It is to the reciprocal advantage of each man to obtain exclusive sexual rights to women and to monopolize their economic productivity. If the evidence from hunter-gatherer life has been correctly interpreted, the exchange has resulted in near universality of the pair bond and the prevalence of extended families with men and their wives forming the nucleus. ${ }^{15}$

In this view pair bonding helped females have four times more children than other primates, giving natural selection four times as many people from whom to select the genes of the smartest, fastest, strongest, and most cooperative to strengthen future generations. This exchange, in short made us human, and, survives to this day to some extent in social rituals, from flirting to engagement rings. ${ }^{16}$

According to Wilson, pair bonding also brought us society itself. Over millennia, he asserts, our prehistoric ancestors extended these reciprocal exchange networks, first between families then eventually - unlike other species - even among strangers. ${ }^{17}$ This last stage defines human society for Wilson:

14 E.O. Wilson, On Human Nature 83, 123, 139 (25th anniversary ed. 2004). See also Fisher, supra note 13, at 101-2; Sarah Blaffer Hrdy, Mothers and Others: The Evolutionary Origins of Mutual UNDERSTANDING 146 (2009).

15 Wilson, supra note 14, at 139 (emphasis added M.E.).

16 Id. at 141.

17 Id. at $1-3$. 


\begin{abstract}
Reciprocation among distantly related or unrelated individuals is the key to human society. The perfection of the social contract has broken the ancient vertebrate constraints imposed by rigid kin selection. Through the convention of reciprocation, combined with a flexible, endlessly productive language and a genius for verbal classification, human beings fashion long-remembered agreements upon which cultures and civilizations can be built. ${ }^{18}$
\end{abstract}

In short, evolutionary research suggests that connection-facilitating exchanges close cousins of markets - are programmed deep into the DNA of family relationships. Therefore, the mere fact that a family begins with a market exchange involving gametes is hardly grounds for condemning it as "unnatural."

\title{
Misperceptions of Reproductive Technologies as Immoral
}

Scholars from a variety of disciplines and ideological perspectives also argue against the market for gametes on moral grounds. Vassar political scientist Mary Lyndon Shanley supports a ban on human gamete sales because we do not own our body parts, but rather hold them as stewards for the next generation. ${ }^{19}$ Social conservative David Blankenhorn critiques sperm markets for creating fatherless families. ${ }^{20}$ Critical race scholar Dorothy Roberts wonders why legal and social mechanisms should facilitate moneyed white people creating babies at any cost, while African American women lack access to reproductive technologies and also face public hostility to their fertility. ${ }^{21}$ Economist Debora Spar and journalist Liza Mundy call for increased regulation of reproductive technology to protect the interests of parents as well as children. ${ }^{22}$ As we saw at the outset of this essay, Margaret Jane Radin, whose canonical critique of marketization of body parts, sex, and babies is best described as commodification skepticism, unequivocally asserts that "[c]onceiving of any child in market rhetoric wrongs personhood."23

18 Id. at 158.

19 Mary Lyndon Shanley, Making Babies, Making Families 92-95 (2001). She does allow for reimbursement of expenses in making donations.

20 David Blankenhorn, Fatherless America: Confronting Our Most Urgent Social Problem 171 (1995). 21 RoBerTs, supra note 7, at 108-9, 246-93.

22 Debora L. Spar, The Baby Business: How Money, Science and Politics Drive the Commerce of Conception, at xviii-xix (2006); Lisa Mundy, Everything Conceivable (2007).

23 RADIN, supra note 1, at 139. 


\section{Concerns about Coercion and Corruption}

But Harvard political theorist Michael Sandel's two-part inquiry represents the most useful way to discern morality-based dangers in contested commodities like gametes. ${ }^{24}$ He looks to whether marketization evidences either coercion or corruption of fundamental social interests or values. ${ }^{25}$ Applying his methodology to gamete markets, I conclude that there is not enough coercion or corruption to justify state interference with the gamete market by banning payment or otherwise. Embryos present a harder case, both because Sandel's corruption argument is stronger and because counter-arguments are weaker.

First, coercion. If a sale is coerced, Sandel reasons, as when a poor person is forced by economic desperation to sell his kidney, then we should not tolerate it. ${ }^{26}$ But even if the kidney sale is fully voluntary, resolving the coercion issue, law still might prohibit the sale if it corrupts something that society holds sacred (such as human life or human bodies).

Applying this analysis to gamete sales leads me to a different conclusion than Sandel reaches. Where he opposes gamete sales, ${ }^{27}$ I do not see problems with coercion. Any corruption in what Sandel calls the replacement of "giftedness" - receipt of a child's qualities from life itself - with "dominion" asserting control over reproductive matters ${ }^{28}$ - seems less troubling than state interference with the dignity and equality of families formed through reproductive technologies, many headed by gay and single parents.

Coercion is an easy case. It is hard to say that college students - male or female - selling their gametes are coerced into doing so, at least in ways that differ from other kinds of employment. The relative lack of fuss about the sperm market in either law or the wider culture may reflect the different expectations of fathers than mothers, as well as the relative ease with which sperm is separated from the human body. Men donate sperm in a painless transaction and may even involve sexual pleasure. Egg extraction, in contrast, involves a minor surgical procedure and powerful drugs. While it is tempting to say that high price for eggs could compel young women to sell what they would otherwise keep, this argument does not hold up under scrutiny. Certainly, the temptation

24 Sandel, What Money Can't Buy, supra note 2; Sandel, The Case Against Perfection, supra note 2 .

25 Sandel, What Money Can't Buy, supra note 2, at 122.

26 Id.

27 Id. at 124; Sandel, The Case Against Perfection, supra note 2, at 1-2, 24, 85.

28 Sandel, The Case Against Perfection, supra note 2, at 85. 
is there. ${ }^{29}$ But the average price for eggs is about \$4,200 per "donation," a multimonth process. ${ }^{30}$ That is not much money for weeks of meetings, medical appointments, injections, and a minor surgery, not to mention behavioral accommodations like abstinence during the process. ${ }^{31}$ If the remuneration is more generous than waiting tables or other work common among college students, it should be.

Corruption is the harder case. Sandel says that gamete markets corrupt the view of life as a gift, "leav[ing] us with nothing to affirm or behold outside our own will." 32 In this view, deaf lesbians Sharon Duchesneau and Candy McCullough improperly sought a deaf sperm donor. ${ }^{33}$ But what if deafness is a culture with its own language and norms instead of a disability? That position, forcefully articulated by deaf activists, suggests that there's nothing wrong with a deaf couple wanting a deaf child, any more than any parents - white, say, Jewish, or African-American - wanting to share a common culture with their children. ${ }^{34}$ Assuming that being deaf is just a difference, not a disability, Sandel is wrong to cast aspersions on those deaf lesbians for selecting deaf sperm donor. Even if deafness is a disability, why should law or society prevent Sharon and Candy from conceiving with sperm from a deaf donor when their straight counterparts in the deaf community can seek each other out as mates? Imagine a state law mandating that deaf couples can only marry if they submit to sterilization, to prevent the birth of deaf children. If that rule would be unjust, it is hard to see what makes it okay for the state or social forces to interfere with a deaf couple selecting a deaf sperm donor.

The same reasoning applies to concerns about anonymous donation. Granted, many sperm and egg donors remain unknown to the children conceived. But increasingly "open donor" policies facilitate contact when the child turns eighteen, as do online registries like the Donor Sibling Registry. ${ }^{35}$ Fertility doctors' ethical guidelines limit the number of children a particular donor

29 See, e.g. Julia Derek, Confessions of a Serial Egg Donor (2004); Roni Caryn Rabin, As Demand for Donor Eggs Soars, High Prices Stir Ethical Concerns, N.Y. Times, May 15, 2007, at F6 (describing a twenty-three-year old woman's egg sale for $\$ 7,000$ to pay off her students loans, a transaction she would not have engaged in but for the payment).

30 Rene Almeling, Sex Cells 118 (2011).

31 Id. at 87-99, 105-8.

32 Sandel, The Case Against Perfection, supra note 2, at 100.

33 Id. at 1-2.

34 See, e.g. Andrew Solomon, Far from the Tree (2012).

35 Wendy Kramer \& Naomi Cahn, Finding Our Families: A First-of-tts-Kind Book for Donor-Conceived People and their Families (2013); https://www.donorsiblingregistry.com/ 
can sire. ${ }^{36}$ There are so many guidelines that it is hardly surprising that some data suggest clinic compliance and some suggest non-compliance. If we do not know whether doctors follow these guidelines, why assert control over these reproductive choices when we don't have the state intervene to prevent promiscuous coital reproduction?

Another line-drawing question arises when we ask whether egg sales corrupt more or differently than sperm sales. Certainly, egg sales more profoundly affect the body and may even diminish donors' ability to become pregnant in the future. Sperm donation does not deprive the donor of much since sperm is regenerated every 3 months, while females are born with their store of eggs for life, so that each donation leaves a woman with fewer eggs with which to create her own family. Moreover, any harm that extraction causes to an egg donor's reproductive system might jeopardize her future fertility. Finally, one could argue that egg sales corrupt the caring aspects of motherhood, in contrast to sperm sales, which seem more consistent with a father's role as provider, an already-monetary relationship. If egg sales harm individual donors, as well as motherhood more generally, more than sperm sales harm donors or social understandings of fatherhood, then perhaps the state ought to prevent women from selling their eggs, while leaving men free to sell their sperm.

Further analysis indicates, however, that these factors do not justify banning egg sales or capping the prices on those sales. Law and culture generally allow people - men and women - to use their bodies as they see fit, from eating junk food to jumping out of planes for fun. Both constitutional norms and contemporary notions of formal equality indicate that law should not make distinctions between men and women absent good reason to do so. Justice concerns are more quickly triggered, in my mind, by banning payment or capping egg prices out of concern that young women will be tempted by high prices to sell what they otherwise would not than by letting medical malpractice and medical ethics police any improprieties. The very dangerousness of the procedure argues the justice of higher compensation, rather than limiting it. Fortunately, existing doctrines offer models for addressing some concerns associated with either coercion or corruption in a more nuanced way than a blunt ban on payment or an incoherent distinction banning payments and allowing reimbursement for expenses, such as Indiana's "recovery costs" capped at $\$ 4,000 .^{37}$

36 Practice Committees of American Society Reproductive Medicine \& Society for Assisted Reproductive Technology, Recommendations for Gamete and Embryo Donation: A Committee Opinion, 99 FERTIL. STERIL. 47, 53 (2013).

37 Ind. Code Ann. § 35-46-5-3(c)(1)(E) (LexisNexis Supp. 2012). 
Indeed, while Sandel makes moral arguments that gamete markets corrupt sacred values like life's "giftedness." ${ }^{38}$ An equally strong case can be made that limiting the market would corrupt something just as important: foundational political norms that, in a free society, prevent government from deciding for people when, whether, how, and with whom to create a family.

\section{Moral Claims to Liberty and Equality}

If we persist in discussing reproductive technologies in term of morals, we should at least add other moral norms to the discussion. In a liberal state, liberty and equality are moral imperatives every bit as important to human dignity as the giftedness of human life. Translated into legal rules, this moral vision protects freedom of action absent evidence that one's actions harm someone else and also polices against giving popular groups more liberty than unpopular or uncommon ones. ${ }^{39}$

The question in an intergenerational justice framework, then, becomes whether markets in gametes - the raw material grows into a human baby if left in a dark warm place for 9 months - harm the babies thus created or children more generally. The ideal of freedom from state meddling in private relationships does a better job of protecting the next generation than a state mandate limiting the type of family a person can form.

\section{Moral Neutrality}

My forthcoming book, currently titled Love \& Contracts, suggests new terms to capture a new, morally neutral, way of describing the different packages in which family love arrives: Plan A and Plan B. Plan A is most common heterosexuality, marriage, kids conceived at home with the fun, free things close at hand - while Plan B covers cohabitation and parenthood through adoption or reproductive technology. Plan B, I contend, is merely uncommon, not unnatural, immoral or unworthy of legal recognition. In this essay I argue that Plan B baby-making through gamete markets does not harm the next generation any more than adoption or Plan A baby-making, and therefore ought not be banned or sharply limited.

38 Sandel, The Case Against Perfection, supra note 2, at 85.

39 John Stuart Mill, On Liberty 172-73 (Gertrude Himmelfarb ed., Penguin Books 1974) (1859). 


\section{Objectification as a Clearer Danger}

Reasonable people disagree with my preference for personal freedom over government interference. Beyond this symposium issue, ${ }^{40}$ Dorothy Roberts worries about limited access and eugenics and others like Naomi Cahn would have the state remedy problems of parental anonymity. ${ }^{41}$ On the other extreme, Judge Richard Posner and Elisabeth Landes argued in 1979 that parenthood through adoption ought to be openly marketized to create incentives for pregnant women not to terminate their pregnancies and move children out of foster care into permanent homes. ${ }^{42}$

But everyone agrees that objectification is a serious concern. Even Landes and Posner stop short of supporting a market in children and would limit remedies for breach of contract in adoption markets. ${ }^{43}$ The question is whether the objectification dangers are greater in gamete markets than in other forms of parenthood. I conclude that they are not unique to the gamete market. Moreover, addressing the concern will itself trigger greater negative effects than allowing the market to continue.

The market for sperm allows women to become pregnant using alternative insemination (AI). ${ }^{44}$ In an article titled "What's Wrong with a Parenthood Market?” I addressed the objectification question in AI:

Importantly, purchasing gametes to conceive a child could cause the child to feel that he or she has been purchased like a new car. Radin claims that "[c]onceiving of any child in market rhetoric harms personhood. ${ }^{25}$ This statement asks us to consider whether the parenthood market, as manifested through adoption and reproductive technologies, treats children like chattel, thus harming their personhood. It is possible to have a market in parenthood, but maintain linguistic mechanisms that mask that reality in order to reassure ourselves and the children that they are different from Corvettes.

40 Elizabeth Bartholet, Intergenerational Justice for Children: Restructuring Adoption, Reproduction \& Child Welfare Policy, 8 (1) L. \& Eтнісs Hum. RTs. (2014).

41 Roberts, supra note 7, at 246-94; NaOmi Cahn, The New Kinship 151-62 (2013).

42 Elisabeth M. Landes \& Richard A. Posner, The Economics of the Baby Shortage, 7 J. LeGAL STUD. 323 (1978). Numerous scholars, myself included, objected to their comparison of foster children to unsold inventory in warehouses and their observation that white babies would command higher prices. See, e.g. Patricia J. Williams, In Search of Pharaoh's Daughter, in Rethinking Commodification, supra note 2, at 68.

43 Landes \& Posner, supra note 42, at 341; Richard A. Posner, Regulation of the Market in Adoptions, 67 B.U. L. Rev. 59 (1987).

44 Martha M. Ertman, What's Wrong with a Parenthood Market? A New and Improved Theory of Commodification, 82 N.C. L. Rev. 1, 26-34 (2003).

45 Radin, Contested Commodities, supra note 1, at 139. 
However, this analysis suggests a monolithic market in which all transactions are interchangeable. Even transactions conventionally understood in market terms, such as insurance, car sales, and housing are governed by different rules that reflect the different contexts. Ambiguities in insurance contracts, for example, are construed against insurers. For their part, car buyers enjoy the implied warranty of merchantability as well as protection in their contractual relationships with financing institutions. Tenants, in turn, are protected by the implied warranty of habitability. The market for parental rights is just one more market with its own unique rules.

Becoming a parent invokes a raft of obligations quite different from those entailed in car ownership. Legally speaking, parents are obliged to, among other things, feed, clothe shelter and educate their child, keep the child out of wage labor, and refrain from discipline that rises to the level of abuse. From an ethical standpoint, parents have the duty to help the child develop a healthy sense of self, become an independent adult, and learn how to be a good citizen. While a car owner is obliged to maintain insurance and refrain from using the car to sell illegal drugs, that owner is also free to destroy the car if she chooses, or run it into the ground through lack of maintenance. Parents are obviously not free to do the same.

In sum, while one might want to guard against language and transactions that treat children as chattel, the mere existence of a market in parenthood does not pose that particular danger.... The mere fact of market rhetoric's presence (or absence), or money changing hands, does not provide us with this crucial information. ${ }^{46}$

Marketing sperm represents the most easily defended element of the market for parental rights. But the reasons for defending it can apply equally well to egg sales. Embryo markets, in contrast, differ somewhat because what is marketed differs, component parts of a baby as opposed to the fertilized egg that matures into a baby. The following section situates this argument within the leading approach in economic sociology.

\section{Connected Lives: A Theoretical Framework for Allowing Gamete Markets}

In a series of field-defining books, Viviana Zelizer argues that money and intimacy overlap in complex ways. ${ }^{47}$ Parenthood, the focus of this essay, operates simultaneously inside and outside of markets, yet lawmakers as well as ordinary citizens routinely perceive an impermeable boundary between the two

46 ERTMAn, supra note 42, at 33-35 (citations omitted (other than Radin quote)).

47 See, e.g. Viviana Zelizer, Pricing the Priceless Child (1985); Viviana Zelizer, The Social Meaning of Money (1994); Viviana Zelizer, The Purchase of Intimacy (2005). For an overview of her approach and an extension to markets in genetic material, see Martha M. Ertman, For Both Love and Money, 37 L. \& Soc. InQ. 1017 (2009). 
realms. Zelizer's contribution is to make sense of the relationship between exchange and intimacy and to reframe it to help us better understand situations where money seems out of place, yet keeps showing up nonetheless.

Zelizer provides terminology to designate what she deems two faulty approaches to the relationship between families and markets, "Hostile Worlds" and "Nothing But." Hostile Worlds' views maintain a sharp division between money and things like love, babies, and body parts, creating a two-dimensional account of family life. In In re Baby $M$ (1988), arguably the most widely discussed case of contested commodification, the New Jersey Supreme Court expressed a Hostile Worlds view of reproductive technologies. It refused to enforce a surrogacy contract between Mary Beth Whitehead and William Stern, asserting that "[t]here are, in a civilized society, some things that money cannot buy." 48 Zelizer systematically debunks Hostile Worlds assumptions by listing a wide range of intimate sexual relationships, each involving different rules regarding economic exchange within the relationship, only some of which are socially or legally forbidden. ${ }^{49}$ For example, she explains, the law of consortium generally entitles a spouse, and only a spouse, to recover money for the loss of companionship, affection, and sexual relations. Palimony, in contrast, entitles nonmarital couples to enforce contractual promises, unless the agreement was meretricious, meaning mainly related to sex. ${ }^{50}$

Zelizer also addresses an equally flawed approach to contested markets, which she calls "Nothing But." The flip side of the Hostile Worlds coin, Nothing But approaches appear less frequently than Hostile Worlds, but they hold particular sway in academic circles. Nothing But views take advantage of Hostile Worlds' failure to account for the obvious overlap of intimacy and money in both life and legal doctrine. Where Hostile Worlds reasoning presupposes a two-dimensional world - market on one side and family on the other Nothing But views reduce social and legal life to one dimension. Nothing But approaches, according to Zelizer, contend that a "simpler principle ... actually explains what is going on." ${ }^{51}$ For example, Chicago School legal economists like Gary Becker and Richard Posner might seem to describe families as Nothing But economic rationality, though I would hasten to add that Posner, at least, makes room for sociobiology as well. ${ }^{52}$ Applied to specific family law problems, Nothing But scholarship could justify post-divorce income sharing on the

48 In re Baby M, 537 A.2d 1227, 1249 (N.J. 1988).

49 Zelizer, Purchase of Intimacy, supra note 47, at 56.

50 Id. at 59.

51 Id. at 29.

52 Gary S. Becker, A Treatise on the Family (1981); Richard A. Posner, Sex \& Reason (1992). 
ground that marriage is a type of long-term contract in which homemaking spouses expect a return on "relationship-specific investments." 53

Zelizer reveals the limits of both Hostile Worlds and Nothing But approaches by enumerating the many areas of overlapping intimacy and markets, including paid carework, compensated foster parents, and family businesses that employ household members. Household members, she explains, consequently develop rights and obligations involving the intersection of intimacy and economic activity. Hostile Worlds formulations of legal doctrine cannot adequately address these issues because they would see paying caregivers as corrupting love, or acknowledging spouses' expectation of candor as corrupting armslength transactions in a family business. A Nothing But framework might mistake paid foster care as Nothing But wage labor like any other, or picking up the tab at a dinner date as the equivalent of pre-paying to sexual access later that evening.

The reductionism of both Hostile Worlds and Nothing But approaches simply fails to reflect the extraordinary complexity of how we live our financial and intimate relationships. We fold a $\$ 10$ bill into a stork to transform plain currency into a gift, and hand our dinner hosts a bottle of wine at the door rather than a $\$ 20$ bill. Even Landes and Posner, arguing for a market in babies, stopped short of advocating markets in older children and specific performance remedies for breach of contract in baby markets. ${ }^{54}$

Zelizer calls her framework, which accounts for the co-constitutive interaction of relationships and exchange, "Connected Lives." It seeks to map the ways that "in everyday life, people invest intense effort and constant worry in finding the right match between economic relations and intimate ties: shared responsibility for housework, spending of household income, care for children and old people, gifts that send the right message, provision of adequate housing for loved ones, and much more." 55 The question Zelizer would have us ask, rather than whether intimates should engage in economic exchanges is "what sorts of economic transactions match which intimate relations." 56 By recognizing overlapping boundaries between intimate and commercial realms, Zelizer reveals analytical errors that underlie both communitarian and hard-line legal economic discourse. In other words, labeling a contest as a competition between dignity, equality and solidarity on one side, and freedom of contract on the other, underappreciates the complex ways that finances and intimacy intersect. My

53 Zelizer, Purchase of Intimacy, supra note 47, at 30.

54 Landes \& Posner, supra note 42, at 341, 344.

55 Zelizer, Purchase of Intimacy, supra note 47, at 3.

56 Id. at 288. 
work seeks to map that midground between commensurability and incommensurability, as does the research of legal scholars such as Carol Rose, Reva Siegel, Margaret Jane Radin, Cass Sunstein, Linda Hirschman and Jane Larson, Martha Nussbaum, Joan Williams. ${ }^{57}$

Zelizer's Connected Lives framework shows that exchanges - both the informal arrangements I call "deals" in my book and legally binding contracts - can facilitate connection as well as separation. This contextual approach better reflects the complex social and legal meaning of money more precisely than an across-the-board communitarian commitment to dignity, solidarity, and equality that argues for demarketizing contested commodities like gametes or a liberal commitment to freedom of contract. Commodification theory need not travel on fixed rails, with one line of thought concluding that markets in parenthood are bad, and another one asserting their benefits. ${ }^{58}$ We can ask a different question than whether or not to commodify parental rights.

Zelizer and law professor Joan Williams suggest we ask who controls and benefits from the transactions. ${ }^{59}$ That framework could help doctrine protect vulnerable parties and also let the law perform its expressive function. The expressive function matters, because regardless of legal prohibitions willing buyers and sellers create markets. They will just be black markets (think illegal drugs, stolen art, and the flourishing, if shameful, slave trade in human beings). The law cannot abolish markets, but it can create incentives and protect some vulnerable parties from some dangers they would face in a black market.

Three hypotheticals help show the wisdom of Zelizer's approach, and how the nuanced readings of different family situations can further the well-being of the children involved.

57 Linda R. Hirschman \& Jane E. Larson, Hard Bargains: The Politics of Sex (1998); Radin, supra note 1; Cass Sunstein, Free Markets and Social Justice (1997); Joan Williams, Unbending Gender: Why Family AND WoRk Conflict and What to do Aвоut iт (2000); Martha C. Nussbaum, "Whether from Reason or Prejudice”: Taking Money for Bodily Services, 27 J. Legal Stud. 693 (1998); Carol M. Rose, Giving, Trading, Thieving, and Trusting: How and Why Gifts Become Exchanges and (More Importantly) Vice Versa, 44 Fla. L. Rev. 295 (1992); Carol M. Rose, Rhetoric and Romance: A Comment on Spouses and Strangers, 82 Geo. L.J. 2409 (1994); Reva Siegel, The Modernization of Marital Status Law: Adjudicating Wives' Rights to Earnings, 1860-1930, 82 Geo. L.J. 2127 (1994); Martha M. Ertman, Marriage as a Trade: Bridging the Private/Private Distinction, Harv. 36 C.R. - C.L. L. Rev. 79 (2001).

58 Martha M. Ertman \& Joan C. Williams, Preface, in Rethinking Commodification, supra note 2, at $2-5$.

59 For a fuller statement of this point, see Joan Williams \& Viviana Zelizer, To Commodify or Not to Commodify: That is Not the Question, in Rethinking Commodification, supra note 2, at 362. 


\section{Hypothetical Cases Showing the Many Meanings of Money}

Imagine Ann and Beth, a lesbian couple, want to have a child. They divide their labor in a way that reflects the joint nature of their endeavor. Ann's younger and healthier, so she agrees to gestate the child that they conceive via alternative insemination with sperm from an anonymous donor. Beth, for her part, signals her engagement in the family by being the one to find a doctor, make medical appointments, research medical procedures, search the web for sperm banks, and pay for the sperm. As they tell their friends and families about the process, they - and others - even use to financial terms like "invest" and "buy-in" to reflect Beth's emotional and social engagement, as in "Beth's really invested in this pregnancy," or "Beth's buy-in was clear from Day 1." Market rhetoric, in short, need not crowd out family bonding. To the contrary, market exchanges can provide a means to create and strengthen family connections. If strong family connections are good for the child Ann and Beth will raise, then the market exchanges that relate to those connections can also, by extension, serve intergenerational justice.

Assume now that Ann and Beth find out that Ann's eggs are past their expiration date, but Beth's eggs are okay. In vitro fertilization allows Ann to carry a child who was conceived with Beth's eggs. Beth, having the better job, pays for this expensive procedure. Because the women are a couple, intending to raise the child together, there is a good chance that family law would treat Ann and Beth both as legal parents, at least if they live in California. ${ }^{60}$ Their implicit agreement to raise the child together provides that child with stability and financial support.

But if Ann and Beth were not lovers, but instead acquaintances who met through work, Beth's payments might signal a different legal relationship. In that case, a good number of states would treat Beth as the sole legal parent and Ann as merely a surrogate mother. ${ }^{61}$ If Ann was the one to pay for everything, especially if she also paid Beth for her egg, then a court would be more likely to see it as an egg sale than a surrogacy arrangement, and treat Ann as the legal mother and Beth a mere egg donor who has no legal relationship to the child. The terms of the contract, in short, tell us more than whether there is a contract or even payment. Legal rules that recognize these transactions can further the interests of the children involved by providing them more stable family arrangements and saving them from drawn out parentage disputes.

60 K.M. v. E.G., 117 P.3d 673 (Cal. 2005).

61 See, e.g. Johnson v. Calvert, 851 P.2d 776 (Cal. 1993). 
These three hypotheticals show that law needs a 3-D view of exchanges in families. In jurisdictions like California with well-developed reproductive technology case law and statutes, family law honors contracts that either create or sever family relationships and also recognizes that emotional details of family life convey crucial information that enables courts to properly assign rights and duties of parenthood. It makes more sense to talk about what kind of contracts are legally recognized, and in which contexts, than to make blanket statements for or against parenthood agreements or exchanges in families more generally.

\section{A “Connected Lives” Take on Gamete Markets}

Having established the power of a Connected Lives approach to contested markets, we now turn to the main subject of this essay, gamete markets. Markets in eggs and sperm - along with sex and body parts markets - present a nodal case for expressing law's role in markets. While prostitution is said to be the oldest profession, these other markets - babies and organs - invite futuristic and idealistic visions. ${ }^{62}$ Babies represent the future. Who, in the public imagination, is more worthy and in need of protection than a baby? If we worry about expanding the role of markets, baby markets present the perfect context for expressing how far contract, and markets, should go in that future. As a positive matter, the question is not whether to start contractualizing parenthood because parenthood is already deeply contractualized. An Internet search for using the terms "sperm bank" and "egg bank" demonstrates that thousands of willing buyers and sellers transact millions of dollars each year. ${ }^{63}$ Birth parents who surrender their children for adoption enter a different kind of legally binding agreement - a contract - to relinquish parental rights and duties, while adoptive parents contract into parental rights and duties. Increasingly, adoptive and birth parents enter open adoption agreements, which often enough include postadoption contact between the children and their birth families through letters, pictures, email, and even in-person contact. ${ }^{64}$

These contracts result in as many as 40,000 babies being born to American families each year due to alternative insemination, another 9500 from egg donation. ${ }^{65}$ At least three times as many U.S. children - between 120,000 and

\footnotetext{
62 Fictional, and dystopic, renditions of these markets include Margaret Atwood, The Handmaid's Tale (1985) and Kazuo Ishiguru, Never Let Me Go (2005).

63 Reproductive technology is a $\$ 3$ billion a year business. Spar, supra note 22, at 3.

64 Joan Heifetz Hollinger, Adoption Law and Practice (2006).

65 Naomi R. Cahn, Test Tube Families 1 (2009).
} 
150,000 - get new parents through adoption contracts each year. ${ }^{66}$ Despite their common contractual underpinnings, reproductive technologies and adoption are regulated quite differently. While reproductive technologies, including egg and sperm sales, remain largely unregulated in the United States, creating a relatively free, open market in which many middle-class people can participate, adoption generally involves state oversight to ensure the child's adoptability and the adoptive parents' fitness. ${ }^{67}$

The following section further illustrates the contractual aspects of adoption. Since many adoptions occur when poverty, illness, or youth prevent birth parents from raising the children they bear, and getting those children adequate love, care, and education is an essential element of intergenerational justice, adoption provides another illustration for the larger point that contractual parenthood need not run contrary to intergenerational justice.

\section{Adoption as Contractualized Plan B Parenthood}

Family law's approach to gamete markets and other parenthood agreements should not be an on/off switch. Instead, the dangers of marketization to intergenerational justice can be contained by social and legal rules that acknowledge the overlaps between markets and intimacy. Adoption provides a case in point.

Some adoption exchanges are legally punished and others legally enforced. Baby-selling is forbidden virtually everywhere, while birth parents enter legally binding agreements - contracts - to sever parental rights and duties, and adoptive parents can formally agree to pay a birth mother's medical, legal, and sometimes living expenses. Sometimes the adults involved enter under-the-table arrangements I call “deals" to distinguish them from legally binding contracts.

One occurs frequently in stepparent adoptions, which account for as many as 75,000 adoptions in the United States each year. Say a biological father owes the mother child support payments - which he is unable or unwilling to pay. If the mother has remarried and wants her new husband to adopt the children, a good number of fathers condition that consent on being released from their pastdue child support obligations. ${ }^{68}$ In addition, the post-adoptive contact agreements, known as PACAs, are treated as mere deals in about half the states.

66 Families by Law: An Adoption Reader 2 (Naomi Cahn \& Joan Heifetz Hollinger eds., 2004) [hereinafter Families by Law].

67 See Fertility Clinic Success Rate and Certification Act of 1992, 42 U.S.C. § 263a-1 (2006); 21 C. F.R. 1271 (2012); Ertman, What's Wrong with a Parenthood Market?, supra note 44, at 24-25.

68 Families by Law, supra note 66; Joan Heifetz Hollinger, State and Federal Adoption Laws, in FAMiLIES By LAW, supra note 66, at 41. 
PACAs have the potential to further intergenerational justice by facilitating adoptions that might not otherwise occur. Imagine a birth mother who cannot raise her child, so she places him with a couple that she hopes will be able to. Many of these birth mothers can only bear to relinquish with the promise of getting information about the child's development through letters and pictures. If a state treats that PACA as a binding contract, perhaps more of the 500,000 children currently languishing in foster care will get adopted into families, finding sorely-needed permanency and stability. ${ }^{69}$

The legal rules governing these contracts, like all agreements pertaining to children, have special provisions to protect those children. First, a PACA does not jeopardize the permanence of a child's placement into a home that adoption professionals call a "forever family." When adoptive parents breach a PACA by cutting off the birth parents' visitation, a court merely orders visitation - as it would in a divorce - and even then only if that contact is in the child's best interests. In contract terms, the remedy for breach is specific performance, not rescission. ${ }^{70}$ Moreover, like all agreements pertaining to children, PACAs are enforceable only if they are consistent with the child's best interests. Consequently, PACAs are not enforceable when a birth parent tries to disrupt the child's relationship with the adoptive family or endangers the child through drink or drugs.

\section{Approaches that Balance Benefits and Dangers of Gamete Markets}

Having explored what scholars say about parenthood contracts, and seen that family law already recognizes parentage-by-contract through adoption, we now turn to what the law says about gamete markets.

\section{Gamete Markets}

The first item to note is that law regulates sperm differently from eggs. Commercial sperm banks are relatively uncontroversial and have generated little

69 C.O. v. Doe, 757 N.W.2d 343 (Minn. 2008); U.S. Dept. Health \& Hum. Svcs, Child Welfare Information Gateway, Post Adoption Contact Agreements between Birth and Adoptive Parents (2011), available at https://www.childwelfare.gov/systemwide/laws_policies/statutes/cooperative.pdf. 70 See, e.g. Mass. Gen. Laws Ann. ch. 210, § 6C(a) (2012). 
regulatory law other than consumer protection regulations like record keeping and donor testing requirements. ${ }^{71}$ But nearly half the states restrict the sales of eggs or embryos to some extent. For example, Louisiana flatly prohibits "the sale of a human ovum, fertilized human ovum, or human embryo."72 Indiana criminalizes the sale of human eggs or embryos, but allows egg donors to be paid up to $\$ 4,000$ for "recovery time" as well as expenses for lost work and travel time. ${ }^{73}$ Virginia, in contrast, excludes "ova ... and other self-replicating body fluids" from its statute criminalizing the sale of body parts and also allows for expense reimbursements. ${ }^{74}$ Maryland takes yet another approach, making selling "unused material" in fertility treatments a misdemeanor. ${ }^{75}$ The Maryland statute, like much of the other state legislation regarding the sale and use of human eggs and embryos, seems aimed to prevent commodification for research, rather than fertility purposes. ${ }^{76}$ It is telling that my research did not yield any statute prohibiting the sale of sperm, a difference that may raise constitutional issues.

Keeping in mind the above discussion about the goals of state involvement in gamete markets, there may be a legitimate reason to regulate sperm differently than eggs, even in a liberal society that does not subject men and women to different rules unless there is good reason to do so. The main concern of the statutes, it seems, is that women might get paid too much. Fertility doctors have agreed to cap egg prices at $\$ 5,000$ with upward departures to $\$ 10,000$ in extraordinary circumstances. ${ }^{77}$ Perhaps coincidentally, gametes are one of the few things that women command a higher price for selling than men do. While men may get paid $\$ 75$ for a sperm donation, women get, on average, $\$ 4,300$ for

71 See supra note 67.

72 La. Rev. Stat. AnN. § 9:122 (2008).

73 IND. CoDE $§ 35-46-5-3$ (b) (LexisNexis Supp. 2012) (“A person who knowingly or intentionally purchases or sells a human ovum, zygote, embryo, or fetus commits unlawful transfer of a human organism, a Class C felony."). The statute does not prohibit paying a "woman donor of an ovum or a qualified third party" for lost earnings, travel expenses, and up to \$4,000 for recovery time in an a "procedure to enhance human reproductive capability" such as IVF. Id. $\S$ 35-46-5-3(c)(1).

74 VA. CodE $\S 32.1-291.16$ (2011). Like the Indiana statute, it allows for "reimbursement of reasonable expenses associated with the removal, processing, preservation, quality control, storage, transportation, implantation, or disposal of a part."

75 Md. Code Ann. Econ. Dev. § 10-439 (LexisNexis 2008).

76 See State Embryonic and Fetal Research Laws, National Conference of State Legislatures (updated Jan. 2008), available at http://www.ncsl.org/issues-research/health/embryonic-andfetal-research-laws.aspx.

77 Am. Soc'y Repro. Med. Ethics Committee, Financial Compensation of Oocyte Donors, 88 FERTIL. STERIL. 305, 307 (2007). 
each egg donation. ${ }^{78}$ The popular press spreads the hype by trumpeting stories of egg sales, noting that elite college newspapers feature advertisements offering up "tens of thousands" of dollars for egg donations. ${ }^{79}$

All that focus on money in egg sales, coupled with lack of concern about men getting paid for their gametes, suggest either an impermissible desire on the part of the state and doctors to control or protect women more than men, or, as plaintiffs have argued in an antitrust case, impermissible price-fixing. ${ }^{80}$ It may even constitute race discrimination because women of color enjoy higher compensation as egg donors than white women because of the scarcity of their eggs in the donor pool. ${ }^{81}$

To my mind, only physical differences like the pain and risk of egg extraction and hormone shots, compared to the harmless experience of donating sperm, could justify differential treatment, and then only if egg donation poses dangers to the donor's short and long-term health. ${ }^{82}$ Any concern about the dangers for society generally, or the children conceived, should apply equally to markets for sperm and eggs.

Regardless of whether law treats male and female gametes the same, it must also determine whether the legal rules regarding gamete sales should be more like those governing children conceived by coitus and or adoption. If assisted reproduction is akin to coitus, then constitutional norms of freedom from government interference with family relationships would sharply limit state interference in gamete markets. If, on the other hand, the purchase of gametes or embryos is more like adoption, then the state has an established role as protector of the would-be child's best interest. We have already said that the permissibility of many adoption-related contracts argues in favor of allowing reproductive technology contracts. Initially, it may seem that the contractual elements common to assisted reproduction and adoption would justify state involvement in reproductive technology arrangements. But while those adoption contracts are highly regulated, enforced only when a court and social workers confirm that the adoption, and its terms, are in the child's best interests that fact need not dictate that the government play as active a role in reproductive technology contracts as it does in adoption contracts.

78 Spar, supra note 22, at 30, 39. Almeling, supra note 30, at 118.

79 Roni Caryn Rabin, As Demand for Donor Eggs Soars, High Prices Stir Ethical Concerns, N.Y. Times May 15, 2007, at F6.

80 Kim Krawiek, Price and Pretense in the Baby Market, in BABY MarkeTs 41 (Michele Goodwin ed., 2009).

81 Almeling, supra note 30, at 69; Lynn Harris, Bionic Parents and Techno-Children, SALon, May 9, 2007, available at http://www.salon.com/2007/05/09/everything_conceivable/.

82 See, e.g. Julia Derek, Confessions of a Serial Egg Donor (2004). 
Different contractual relationships have different levels of state intervention in the terms of those agreements. Minimum wage laws provide baseline compensation terms in employment relationships, and the warranty of habitability provides requires that rented housing provides basic amenities like heat and hot water. While over-the-counter drugs are subject to federal regulations, vitamins and other dietary supplements are not. ${ }^{83}$

Where Naomi Cahn would treat assisted reproduction more like adoption and therefore seeks increased state engagement in gamete markets with, for example, donor registries - I find Glenn Cohen's analogy to coitus more persuasive. ${ }^{84}$ Neither gametes nor even embryos are children. As Michael Sandel says to justify his support for stem cell research, an acorn may grow into an oak tree, but it is still just an acorn. ${ }^{85}$ Along the same lines, gametes will not become human beings without being gestated and all that entails.

Even if the dangers to the people involved or society more widely are greater in gamete sales than coital reproduction, those concerns could be addressed in consumer-protection type regulations without unduly limiting access to these markets. Law often expresses a social value by dictating the terms of the sale. ${ }^{86}$ For example, pharmaceutical drugs are marketized in a controlled way that allows only physicians to authorize the sale, and only pharmacists to dispense the drugs. Similarly, most workers must make at least the minimum wage, and work conditions must satisfy health and safety laws. ${ }^{87} \mathrm{Egg}$ and sperm sales might be regulated in like fashion if there are health risks to donors or the children conceived that are akin to risks associated with drugs or vitamins.

Tort law or insurance law could impose limits by, for example, designating egg retrieval from a female under 18 years of age as negligence and therefore not insurable. Just as minors generally lack the capacity to contract, contract law already bars very young people from entering contracts to donate their gametes. If the donation of eggs poses particular dangers to long-term reproductive health, legal doctrine could further limit the conditions of the sale, perhaps by requiring donors be at least 21 , the age when law and society allow young adults fit to do other dangerous things, like drink alcohol. None of these interventions

83 Paul Ofitt, Don't Take Your Vitamins, NY Times, June 8, 2013.

84 Cahn, The New Kinship, supra note 41, at 143; I. Glenn Cohen, Response: Rethinking SpermDonor Anonymity: Of Changed Selves, Non-Identity and One-Night Stands, 100 Geo. L.J. 431 (2012). 85 Sandel, The Case Against Perfection, supra note 2, at 116.

86 Arjun Appadurai, Introduction, The Social Life of Things 3 (1986), reprinted in Rethinking Commodification, supra note 2, at 34.

87 Fair Labor Standards Act, 29 U.S.C. §§ 201-219 (2006); Occupational Safety \& Health Act, of 1970, Pub. L. No. 91-596 (codified as amended in scattered sections of 19 U.S.C.). 
interferes with the larger justice interests of recognizing that families come in different packages.

\section{Embryos}

Embryos present a harder case, since they are a step closer to human beings than gametes. Sperm banks such as the California Cryobank and the Fairfax Cryobank store embryos for a fee. ${ }^{88}$ But storage is a far cry from sale, a fact illustrated that newspapers across the globe covered the expansion of parenthood markets into sale of formed embryos (as opposed to egg and sperm) by a small company, the Abraham Center for Life in San Antonio, Texas. ${ }^{89}$ The outcry seems to have nipped the market in the bud, as a 2007 visit to the Abraham Center for Life's website reports that it discontinued its "human embryo bank" because it was not cost effective. ${ }^{90}$ That market may have barely existed. Jenalee Ryan, who founded the Abraham Center founder, admitted "it's a bank without anything in it,"91 during the height of the media flurry in January 2007 that surrounded her founding of the company. Five years later, in 2012, the LA Times reignited the controversy by reporting that one clinic reduces costs by creating embryos from eggs from one donor and sperm from another donor, then distributing the embryos to several patients. ${ }^{92}$

In case a market does emerge, the American Society for Reproductive Medicine declared in 2013 that "the selling of embryos per se is ethically unacceptable." 93 That market, which seems largely hypothetical, at least for the moment, nevertheless represents a significant step in marketizing parenthood beyond the commodification of eggs and sperm.

88 California Cryobank, available at http://www.cryobank.com (last visited Nov 15, 2013); FaIRfaX CRYobank, available at http://www.fairfaxcryobank.com (last visited Jan. 27, 2014).

89 See, e.g. Osagie K. Obasogie, Op-Ed., "Walmartization” of Embryos, Boston Globe, Feb. 1, 2007, at A9; Carol Midgley, Embryos for Sale, THe Times (London), Jan. 12, 2007, at 4.

90 http://www.theabrahamcenterforlife.com/index4.html (last visited July 2, 2007).

91 Joe Palca, Adoption Agency Offers Up Embryos to Couples, Npr News, Jan. 8, 2007, available at http://www.npr.org/templates/story/story.php?storyId=6749036. Other news coverage detailed Ryan's production of twenty-two embryos from a twenty - something egg donor in Arizona and a six-foot blonde lawyer whose sperm she purchased from the Fairfax Cryobank, and two pregnancies that apparently resulted from her arrangements with a New York fertility clinic. 92 I. Glenn Cohen \& Eli Y. Adashi, Made-to-Order Embryos for Sale: A Brave New World?, 368 N.E. J. MED. 2517 (April 29, 2013), available at http://www.nejm.org/doi/full/10.1056/NEJMsb1215894. 93 Practice Committee of ASRM and SART, Recommendations for Gamete and Embryo Transfer: A Committee Opinion 99 Fertility \& Sterility 47 (2013). 
Rather than banning transactions in embryos, law could instead cabin the downsides of an embryo market by controlling the mechanisms of the sale by, for example, banning auctions - including eBay - since they evoke images of human beings on the auction block, a practice long repudiated under the Thirteenth Amendment's prohibition on slavery. Indeed, eBay already has a policy against posting humans and body parts. ${ }^{94}$ Law and medical practice also could limit what kinds of institutions create and sell embryos through legal doctrines that target the problem - health threats to donors, for example instead of falling into Hostile Worlds trap of seeing the exchange of money for eggs or embryos as the real problem.

\section{Conclusion}

Intergenerational justice does not require increased government regulation of reproductive technologies in the United States. Arguments tarring reproductive technologies as unnatural or immoral fail to withstand close scrutiny; and moreover ignore competing moral concerns like the liberty and equality of people to form families in different ways, as well as the interests of children born via assisted reproduction in having their families recognized just as coitally conceived children's families are recognized. Embryo markets, in contrast, might present different challenges, requiring a separate analysis of their potential impact on intergenerational justice.

Acknowledgments: Thanks are due to the University of Maryland Carey Law School for providing generous research support, its librarians, especially Susan Herrick, for providing able research support, and Gila Stopler, Pamela LaufferUkele, Shelly Levy-Kreiczer, and the participants at the College for Law and Business conference on "Intergenerational Justice" for helpful comments on a related paper I presented there.

Note: This essay further develops ideas published in a chapter titled The Upside of Baby Markets in BABY Markets (Michele Goodwin ed., 2009), published by Cambridge University Press.

94 Human Remains and Body Parts Policy, EBAY, available at http://pages.ebay.com/help/ policies/remains.html (last visited Nov 15, 2013). 